\title{
PENGARUH KEDISIPLINAN, KOMPENSASI DAN BUDAYA ORGANISASI TERHADAP KINERJA KARYAWAN PT. ADI RAYA CONSTRUCTION GRESIK
}

\author{
Alfiani Rosyadah \\ Program Studi Manajemen Fakultas Ekonomi dan Bisnis \\ Universitas Muhammadiyah Gresik
}

\begin{abstract}
The purpose of this study to determine the influence of discipline, compensation and organizational culture on employee performance at PT. Adi Raya Construction Gresik. The sample used proportionate stratified random sampling technique with 77 employee sampling using krejcie table with error size 5\%. Data analysis techniques use multiple linear regression. Results of multiple linear regeresis proves that discipline, compensation and organizational culture is shown to have a partially significant effect on the performance of employees of PT. Adi Raya Construction Gresik. These results can be interpreted that the existence, discipline, compensation and organizational culture that has been applied to improve employee performance in PT. Adi Raya Construction Gresik.
\end{abstract}

Keywords: Discipline, compentation and Cultural Organization

\section{PENDAHULUAN}

Kinerja atau Performance merupakan gambaran mengenai tingkat pencapaian pelaksanaan suatu program kegiatan atau kebijakan dalam mewujudkan sasaran, tujuan, visi dan misi organisasi yang dituangkan melalui perencanaan strategis suatu organissi Moeheriono (2012;95). Banyak faktor yang mempengaruhi kinerja karyawan, salah satunya yakni Kedisiplinan, kompensasi dan budaya organisasi. PT. Adi Raya Construction Gresik adalah salah satu perusahaan terbilang baru dibidang kontruksi, berdiri empat tahun yang lalu PT. Adi Raya Construction mampu bersaing ketat dengan perusahaan-perusahaan kontruksi besar lainya dengan didukung teknologi yang canggih, terbukti beberapa perusahaan besar seperti PT. PAL Indonesia, PT. Pertamina (Persero), dan PT. Wilmar Nabati Indonesia pernah menjadi pihak pengguna jasa PT. Adi Raya
Construction Gresik. Kinerja karyawan yang tinggi sangatlah diharapkan oleh perusahaan, semakin banyak karyawan yang mempunyai kinerja tinggi, maka produktivitas perusahaan secara keseluruhan akan meningkat baik sehingga perusahaan dapat bertahan dalam persaingan global. Karyawan PT. Adi Raya Construction Gresik dituntut untuk mampu menyelesaikan tugas sesuai target yang diharapkan, kerjasama yang baik serta management controlling yang kuat, bagi PT. Adi Raya Construction Gresik tiga indikator tersebut sangat penting untuk dilakukan dengan baik agar perusahaan dapat bertahan dan bersaing dengan perusahaan kontruksi lain serta pihak pengguna jasa pun merasa puas terhadap kinerja karyawan PT. Adi Raya Construction Gresik.

Berdasarkan data tingkat kepuasan pihak pengguna jasa terhadap kinerja karyawan PT. Adi 
Raya Construction Gresik menunjukan bahwa $75 \%$ pihak pengguna jasa sangat puas terhadap kinerja karyawan pada indikator teamwork, $62.5 \%$ pada indikator Target dan $50 \%$ pada indikator management controlling. Artinya dua dari tiga indikator tersebut menunjukan bahwa lebih dari 50\% pihak penggguna jasa merasa sangat puas terhadap kinerja karyawan PT. Adi Raya Construction Gresik. Menurut salah satu client atau pihak pengguna jasa internal teamwork karyawan PT. Adi Raya Construction Gresik sangat baik, speedup atau kecepatan pekerjaan bisa ditargetkan tetapi management controlling harus lebih diperkuat lagi.

Kedisiplinan merupakan hal yang sangat penting yang harus dijalankan, khusunya PT. Adi Raya Construction Gresik Kedisplinan merupakan sikap mental yang harus dimiliki oleh seseorang untuk mematuhi peraturan dan ketentuan yang berlaku diperusahaan dengan tertib. Disiplin kerja yang telah dilakukan pada karyawan PT. Adi Raya Construction Gresik berjalan dengan baik dan dilakukan sesuai peraturan yang ditetapkan serta dengan penuh rasa tanggung jawab. Hal ini dapat dilihat dari data tingkat kepuasan pihak pengguna jasa terhadap kinerja karyawan pada indikator target, ini artinya setiap pekerjaan selesai tepat waktu sesuai target yang ditentukan. Kedisiplinan menjadi hal yang sangat penting yang harus dilakukan oleh seluruh karyawan PT. Adi Raya Contruction Gresik, sebab dengan kedisiplinan yang baik seperti hadir tepat waktu, disiplin dalam penggunaan alat pekerjaan serta bekerja sesuai prosedur, pekerjaanpun juga akan selesai tepat waktu sesuai target.
Untuk meningkatkan kinerja dan menjaga kepuasan pihak pengguna jasa kiranya PT. Adi Raya Construction memberikan sebuah proses dorongan yang dilakukan perusahaan kepada karyawanya dalam bentuk pemberian kompensasi. Karena kinerja di PT. Adi Raya Construction sangatlah penting untu menunjang kualitas dan ketepatan waktu untuk menyelesaikan sebuah proyek yang sudah dipercayakanya. PT. Adi Raya Construction Gresik sangat memikirkan komponen gaji yang diberikan kepada karyawanya. PT. Adi Raya Construction Gresik memberikan kompensasi secara Finansial dan Nonfinansial, sedangkan untuk kompensasi Finansialnya perusahaan juga menerapkan Finansial langsung dan tidak langsung. Namun bukan berarti tidak ada kendala dalam pemberianya, tidak tepat waktu dalam pemberianya menjadi persoalaan yang ada dalam perusahaan..

Budaya Organisasi adalah suatu sistem nilai dan keyakinan bersama yang diambil dari pola kebiasaan dan falsafah dasar pendirinya yang kemudian berinteraksi menjadi normanorma, dimana norma tersebut dipakai sebagai pedoman cara berfikir dan bertindak dalam upaya mencapai tujuan bersama. Budaya organisasi yang diterapkan oleh PT. Adi Raya Construction Gresik guna meningkatkan kinerja pegawai diantaranya, Integritas, Profesional, Dinamis, Trust, Keamanan Lingkungan, Kreatifitas, Goal Oriented dan Teamwork. Berdasarkan uraian latar belakang diatas maka dapat diajuakan sebuah penelitian dengan judul "Pengaruh Kedisiplinan, Kompensasi, dan Budaya Organisasi Terhadap Kinerja Karyawan PT. Adi Raya Contruction" 


\section{TINJAUAN PUSTAKA}

Penelitian yang dilakukan Dipta Adi Prawatya (2012) berjudul "Pengaruh Disiplin Kerja Dan Budaya Organisasi Terhadap Kinerja Karyawan Pabrik Minyak Kayu Putih (Pmkp) Di Krai Purwodadi", Penelitian menggunakan variabel disiplin (X2), motivasi (X2), budaya organisasi (X3) dan kinerja karyawan (Y). Dalam menganilisis dengan teknik analisis regresi linier berganda. Hasil penelitian ini bahwa disiplin kerja berpengaruh positif dan signifikan terhadap kinerja karyawan Pabrik Minyak Kayu Putih (PMKP). Budaya organisasi berpengaruh positif dan signifikan terhadap kinerja karyawan Pabrik Minyak Kayu Putih (PMKP) Purwodadi.

\section{Manajemen Sumber Daya Manusia} Ardana dkk (2012:5) mendefinisikan Manajemen Sumber Daya Manusia adalah suatu proses pemanfaatan SDM secara efektif dan efisien melalui kegiatan perencanaan, penggerakan dan pengendalian semua nilai yang menjadi kekuatan manusia untuk mencapai tujuan. Sementara Ardana dkk (2012:5) Manajemen Sumber Daya Manusia didefinisikan sebagai rangkaian strategi, proses dan aktivitas yang didesain untuk menunjang tujuan perusahaan dengan cara integrasi kebutuhan perusahaan dan individu.

\section{Kedisiplinan}

Disiplin berasal dari akar kata disciple berarti belajar. Disiplin merupakan arahan untuk melatih dan membentuk seseorang melakukan sesuatu menjadi lebih baik. Disiplin adalah suatu proses yang dapat menumbuhkan perasaan untuk meningkatkan dan mempertahankan tujuan organisasi secara obyektif, melalui kepatuhanya menjalankan peraturan organisasi.
Disiplin sangat penting untuk pertumbuhan organisas, di gunakan terutama untuk memotivasi pegawai agar dapat mendisiplinkan diri dalam melaksanakan pekerjaan baik secara perorangan maupun kelompok.

\section{Kompensasi}

Pengertian kompensasi adalah segala sesuatu yang diterima oleh karyawan sebagai balas jasa atas upaya-upaya yang telah diberikan kepada perusahaan. Kompensasi sangat dipengaruhi oleh tekanan-tekanan faktor-faktor pasar kerja, posisi rebut tawar kolektif, peraturan pemerintah, filosofi manajemen puncak tentang pembayaran dan manfaat termasuk tentang kompensasi internasional (Mangkuprawira, 2014;28). Kompensasi merupakan sesuatu yang diterima karyawan sebagai penukar kontribusi jasa pada perusahaan.

Kompensasi merupakan faktor utama dalam kepegawaian. Kebijakan kepegawaian banyak berhubungan dengan pertimbangan menentukan kompensasi. Tingkat besar kecilnya kompensasi sangat berkaitan dengan tingkat pendidikan, tingkat jabatan, dan masa kerja. Maka dari itu dalam menentukan kompensasi karyawan perlu didasarkan penilaian prestasi, kondisi pegawai, tingkat pendidikan, jabatan dan masa kerja.

\section{Budaya Organisasi}

Menurut Kreitner dan Kinicki $(2014 ; 62)$ budaya organisasi adalah nilai dan keyakinan bersama yang mendasari identitas perusahaan. Hal yang sama juga diungkapkan oleh Mangkunegara (2009: 113) yang menyatakan bahwa budaya organisasi adalah seperangkat asumsi atau sistem keyakinan, nilai-nilai, dan norma yang dikembangkan dalam organisasi yang dijadikan pedoman tingkah laku bagi 
anggota-anggotanya untuk mengatasi masalah adaptasi eksternal dan internal. Dengan demikian dapat disimpulkan bahwa budaya organisasi merupakan pola keyakinan dan nilainilai organisasi yang diyakini dan dijiwai oleh seluruh anggotanya dalam melakukan pekerjaan sebagai cara yang tepat untuk memahami, memikirkan, dan merasakan terhadap masalah-masalah.

\section{Kinerja}

Menurut Mangkunegara kinerja $(2013 ; 67)$ mendefinisikan hasil kerja secara kualitas dan kuantitas yang dicapai oleh seseorang karyawan dalam kemampuan melaksanakan tugas-tugas sesuai dengan tanggung jawab yang diberikan oleh atasan kepadanya. Bernardin dan Russel dalam Sutrisno $(2014 ; 149)$ kinerja adalah catatan tentang hasil yang diperoleh dari pekerjaan tertentu atau kegiatan tertentu selama kurun waktu tertentu. Kinerja merupakan perilaku nyata yang ditampilkan setiap orang sebagai prestasi kerja yang dihasilkan sesuai dengan perannya di perusahaan (Rivai dan Sagala, 2013;548).

Dari beberapa pendapat diatas dapat disimpulkan bahwa kinerja merupakan hasil kerja yang telah dicapai seseorang dari tingkah laku kerjanya dalam melaksanakan aktivitas kerjanya dalam rangka upaya mencapai tujuan organisasi dan sesuai dengan hukum, moral maupun gambaran mengenai tingkat pencapaian pelaksanaan suatu kegiatan/program kebijaksanaan.

\section{Hubungan Antar Variable \\ Hubungan Kedisiplinan Dengan Kinerja}

Menurut Hasibuan (2013; 23) kedisiplinan merupakan fungsi manajemen Sumber Daya Manusia yang terpenting dan kunci terwujudnya tujuan karena tanpa disiplin yang baik sulit terwujud tujuan yang maksimal. Disiplin merupakan salah satu hal yang harus terus dijaga dan ditingkatkan secara terus menerus agara karyaawan menjadi terbiasa bekerja dengan penuh kedisiplinan dan tanggung jawab sesuai dengan tugas yang telah diberikan oleh perusahaan. Disiplin kerja mempunyai pengaruh positif terhadap kinerja karyawan. Karyawan yang disiplin dalam bekerja sejak berangkat, saat kerja dan saat pulang kerja serta sesuai aturan dalam bekerja, biasanya akan memiliki kinerja yang baik. Dapat disimpulkan, semakin tinggi disiplin kerja, maka semakin tinggi kinerja karyawan.

\section{Hubungan Kompensasi Dengan Kinerja}

Dua hal yang perlu diingat perusahaan dalam pemberian kompensasi. Pertama kompensasi yang diberikan perusahaan harus dapat dirasakan adil oleh karyawan dan kedua, besarnya kompensasi tidak jauh berbeda dengan yang diharapkan oleh karyawan. Apabila dua hal ini dapat dipenuhi, maka karyawan akan merasa puas. Kepuasan akan memotivasi karyawan untuk meningkatkan kinerjanya, sehingga tujuan perusahaan maupun kebutuhan karyawan akan tercapai secara bersama. Moheriono (2012; 208) jika kompensasi diterapkan secara efektif, akan memiliki dampak positif bagi organisasi karena dapat meningkatkan kinerja serta memberikan kepuasan kerja pegawai.

$\begin{array}{lr}\text { Hubungan Budaya } & \text { Organisasi } \\ \text { Dengan Kinerja } & \\ \text { Budaya organisasi yang } & \text { positif akan } \\ \text { membentuk komitmen } & \text { karyawan } \\ \text { terhadap perusahaan. } & \text { Karyawan }\end{array}$


mendukung tujuan organisasi, senang dalam bekerja dan berinteraksi dengan rekan kerja menekan kemungkinan negative karyawan untuk mangkir dari pekerjaanya. Dipaparkan dalam jurnal dengan judul Impact of Organizational Culture on Organizational Performance: An overview yang dilakukan oleh Shahzad, Lukman, Khan dan Shabbir dalam Interdicipline Journal of Contemporary Research in Business (2012; 975) bahwa budaya organisasi memiliki dampak yang positif pada kinerja karyawan yang dapat meningkatkan produktivitas dan memningkatkan kinerja organisasi.

\section{Hipotesis}

Berdasarkan latar belakang dan permasalahan yang ada diarahkan untuk merujuk pada dugaan sementara, yaitu:

1. Diduga adanya pengaruh
kedisiplinan secara parsial
terhadap kinerja karyawan.

2. Diduga adanya pengaruh kompensasi secara parsial terhadap kinerja karyawan.

3. Diduga adanya pengaruh budaya organisasi Kerja secara parsial terhadap kinerja karyawan.

4. Diduga adanya pengaruh kedisiplinan, kompensasi dan budaya organisasi secara simultan terhadap kinerja karyawan.

\section{METODOLOGI PENELITIAN}

Penelitian ini menggunakan pendekatan kuantitatif. Penelitian ini dilaksanakan di PT. Adi Raya Construction Gresik. Adapun populasi dalam penelitian ini adalah Seluruh Karyawan PT. Adi Raya Construction Gresik pada proyek di PT. Wilmar Nabati Indonesia. Data primer yang digunakan dalam penelitian ini adalah terkait Kinerja karyawan,
Kedisiplinan, Kompensasi dan Budaya Organisasi.

Ada 4 variabel dalam penelitian ini, variable bebas adalah Kedisiplinan (X1) Kompensasi (X2) Budaya Organisasi (X3) sedangkan variable terikat adalah Kinerja usaha (Y). definisi operasional variable dalam penelitian ini sebagai berikut: Kedisiplinan (X1) Kedisiplinan adalah kesadaran dan kesediaan karyawan PT. Adi Raya Construction dalam mentaati semua peraturan perusahaan dan norma-norma sosial yang berlaku Kompensasi (X2) Kompensasi adalah kegiatan untuk menghargai usaha dan, jasa dan prestasi karyawan PT. Adi Raya Construction yang telah memberikan kontribusinya melalui pelaksanaanya dalam mencapai tujuan perusahaan. Budaya Organisasi (X3) Serangkaian nilai-nilai, keyakinankeyakinan, asumsi-asumsi, yang telah berlaku dan disepakati dan diikuti oleh seluruh karyawan PT. Adi Raya Construction. Kinerja (Y) Perilaku nyata yang ditampilkan setiap karyawan PT. Adi Raya Construction sebagai prestasi kerja yang dihasilkan sesuai tugasnya dalam perusahaan.

Pada penelitian ini teknik analisis data menggunakan pengujian hipotesis dengan menggunakan uji statistik, yaitu melalui analisis regresi. Teknik ini untuk mengetahui pengaruh dari masing-masing variabel independen berpengaruh positif atau negatif terhadap variable dependen.

\section{HASIL PENELITIAN}

Gambaran Umum Objek Penelitian

PT. Adi Raya Construction Berdiri 11 Oktober 2010, mulai dari CV.Adi Raya Construction memulai dari pekerjaan konstruksi sampai sekarang tumbuh untuk perusahaan go public Dengan EPC (Engineering, Procurement, dan Construction) 
Perusahaan. Pada saat ini PT. Adi Raya Construction berkomitmen untuk meningkatkan kinerja perusahaan dengan melakukan restrukturisasi secara menyeluruh, mulai dari visi dan misi, struktur organisasi, SDM, sistem informasi, sampai dengan manajemen risiko di dalam kontruksi. Komitmen perusahaan dibangun dengan tujuan untuk meningkatkan kepuasan pelanggan secara nyata dengan menghasilkan karya konstruksi yang berkualitas dan tepat waktu. Sebagai misi strategis PT. Adi Raya Construction Indonesia memanfaatkan kekuatan dalam jaringan mendukung dan kemitraan profesional mengatur karya layanan rantai pasokan dan proyek EPC dalam sumber keahlian internal dan keahlian khusus termasuk outsourcing tetapi tidak terbatas pada Teknik, Produsen, Transportasi fabrikasi Yard, dan Konstruksi kinerja fasilitas.

\section{Interpretasi Hasil}

Penelitian ini bertujuan untuk melihat apakah Kedisiplinan, Kompensasi dan Budaya Organisasi berpengaruh signifikan secara parsial dan simultan terhadap Kinerja Karyawan PT. Adi Raya Construction Gresik. Berdasarkan penelitian dan analisis yang dilakukan dengan menggunakan alat bantu SPSS 23, maka peneliti dapat menginterpretasikan hasil sebagai berikut:

\section{Kedisiplinan (X1) terhadap Kinerja}

Berdasarkan hasil pengujian yang telah dilakukan, dapat dibuktikan dengan nilai sig $0,016<0,05$ sehingga menunjukkan bahwa untuk variabel Kedisiplinan (X1) pada PT. Adi Raya Construction Gresik berpengaruh positif dan signifikan terhadap kinerja. Sehingga teori Hasibuan $(2011 ; 193)$ yang menyatakan semakin baik disiplin karyawan maka semakin tinggi kinerja yang dapat dicapainya dan penelitian Dipta Adi Prawatya (2012) bahwa terbukti kedisiplinan berpengaruh positif dan signifikan terhadap kinerja karyawan.

\section{Kompensasi (X2) Terhadap Kinerja}

Berdasarkan hasil pengujian yang telah dilakukan, dapat dibuktikan dengan nilai sig $0,008<0,05$ sehingga menunjukkan bahwa untuk variabel Kompensasi (X1) pada PT. Adi Raya Construction Gresik berpengaruh positif dan signifikan terhadap kinerja. Sehingga teori menurut Moheriono (2012; 208) yang menyatakan bahwa salah satu cara untuk meningkatkan kinerja karyawan yakni melalui kompensasi dicapainya dan penelitian Yuli suwatai (2013) bahwa terbukti kompensasi berpengaruh positif dan signifikan terhadap kinerja karyawan.

\section{Budaya Organisasi (X3) Terhadap Kinerja (Y)}

Berdasarkan hasil pengujian yang telah dilakukan, dapat dibuktikan dengan nilai sig $0,001<0,05$ sehingga menunjukkan bahwa untuk variabel Budaya Organisasi (X1) pada PT. Adi Raya Construction Gresik berpengaruh positif dan signifikan terhadap kinerja. Sehingga teori menurut Mcshane dan Von Glinow dlam (Widodo 2011) mengatakan budaya organisasi yang kuat memiliki potensi meningkatkan kinerja dan sebaliknya bila budaya organisasi lemah mengakibatkan inerja menurun dan seperti apa yang di dipaparkan dalam jurnal dengan judul Impact of Organizational Culture on Organizational Performance: An overview yang dilakukan oleh Shahzad, Lukman, Khan dan Shabbir dalam Interdicipline Journal of Contemporary Research in Business 
(2012; 975) bahwa budaya organisasi memiliki dampak yang positif pada kinerja karyawan yang dapat meningkatkan produktivitas dan meningkatkan kinerja organisasi.

\section{Kedisiplinan (X1) Kompensasi (X2) Budaya Organisai (X3) Terhadap Kinerja}

Nilai regresi memiliki tingkat signifikansi 0,00 nilai ini lebih kecil dari 0,05 atau nilai signifikansi $<\alpha$ dan $F_{\text {hitung }}$ memiliki nilai 14.805 sedangkan $\mathrm{F}_{\text {tabel }}$ memiliki nilai 2.716 ini berarti $F_{\text {hitung }}>F_{\text {tabel }}$, sehingga Ho ditolak dan Ha diterima, artinya secara simultan terbukti ada pengaruh signifikan Kedisiplinan $\left(\mathrm{X}_{1}\right)$, kompensasi $\left(\mathrm{X}_{2}\right)$, Budaya Organisasi $\left(\mathrm{X}_{3}\right)$, terhadap kinerja karyawan $(\mathrm{Y})$.

\section{KESIMPULAN \\ REKOMENDASI}

DAN

\section{Kesimpulan}

Berdasarkan hasil peneltian maka penelti dapat menyimpulkan.

1. Variabel Kedisiplinan (X1) menunjukkan pengaruh parsial dan signifikan terhadap kinerja.

2. Variabel Kompensasi menunjukkan tidak berpengaruh parsial dan signifikan terhadap kinerja.

3. Variabel Budaya Organisasi (X1) menunjukkan pengaruh parsial dan signifikan terhadap kinerja.

4. Variabel Kedisiplinan (X1) Kompensasi (X2) Budaya Organisasi (X3) Secara simultan berpengaruh signifikan terhadap kinerja.

\section{Rekomendasi}

Berdasarkan hasil penelitian yang dilakukan, maka peneliti memberikan rekomendasi sebagai berikut:

1. Bagi Aspek Manajerial
Pada variabel Kedisiplinan $\left(\mathrm{X}_{1}\right)$ hasil $\mathrm{t}$ hitung mendapat nilai terendah dibandingakan dengan variabel Kompensassi $\left(\mathrm{X}_{2}\right)$ dan Budaya Organisasi $\left(\mathrm{X}_{3}\right)$ Manajemen PT. Adi Raya Construction Gresik harus mampu dan terus meningkatkan Kedisiplinan kepada karyawan dengan memberikan kebijakan maupun peraturan-peraturan agar di patuhi oleh karyawan, sebab dengan disiplin yang baik seperti hadir tepat waktu, disiplin dalam penggunaaan alat pekerjaan serta bekerja sesuai prosedur, pekerjaanpun juga akan selesai tepat waktu sesuai target yang ditetapkan.

2. Bagi peneliti selanjutnya

Bagi peneliti selanjutnya hendaknya mempertimbangkan untuk menambahkan variabel lain diluar variabel yang diteliti dalam penelitian ini seperti, Kesehatan dan Keselamatan Kerja, Motivasi Kerja, Lingkungan Kerja, kepuasan kerja serta menggunakan teknik analisis berbeda untuk mengetahui perbedaan analisis satu dengan analisis lainya seperti teknik analisis multivariate regression.

\section{DAFTAR PUSTAKA}

Ardhana, I Komang., Mujiati Ni Wayan., Utama, I Mudiartha, 2012, Manajemen Sumber Daya Manusia ,. Graha Ilmu, Yogyakarta.

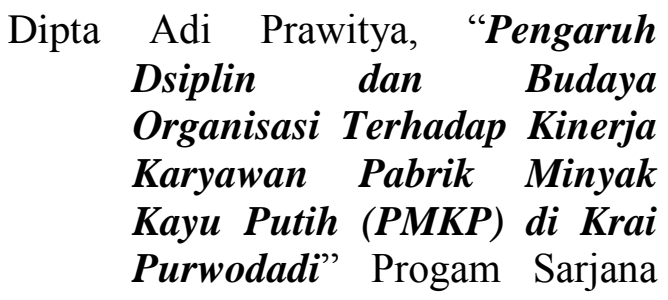


Fakultas Ekonomi Universitas Diponegoro, Semarang.

Hasibuan, Melayu S. P.,2013, Manajemen Sumber Daya Manusia, PT. Bumi Aksara Jakarta

Mangkunegara, Anwar Prabu, 2013, Manajemen Sumber Daya Manusia Perusahaan, PT. Remaja Rosdakarya, Bandung.

Rivai, Veithzal Ella Jauvani Sagala, 2013, Manajemen Sumber Daya Manusia Untuk Perusahaan dari Teori dan Praktik, Cetakan Ke-5, PT Rajagrafindo Persada, Jakarta.

Sugiyono. 2014. Metode Penelitian

Kuantitatif,Kualitatif, dan Kombinasi (Mixed Methods). Bandung : Alfabeta.

Suhardjono, (2003). Manajemen Perkreditan Usaha Kecil dan Menengah. Jakarta: UPP AMP YKPN Ikut Mencerdaskan Bangsa.

Sutrisno. (2009), Manajemen Keuangan Teori, Konsep, dan Aplikasi. Yogyakarta.Todaro, Michael P dan Smith, Stephen C. 2006. PembangunanEkonomi, Jakarta: Erlangga. 